\title{
GAMBARAN KADAR SGPT ( SERUM GLUTAMIC PYRUVIC TRANSAMINASE ) PADA PEROKOK AKTIF DI USIA 17 - 25 TAHUN DENGAN LAMA MEROKOK $<10$ TAHUN
}

\author{
${ }^{1}$ Kresna Latafodes Wicaksana, ${ }^{2}$ Riky, ${ }^{3}$ Nur Aini Hidayah Khasanah \\ ${ }^{1,2,3}$ Stikes Borneo Cendekia Medika Pangkalan Bun \\ Email :Wicak607@gmail.com
}

\begin{abstract}
Abstrak : Data WHO (World Health Organization) Indonesia menduduki peringkat ketiga sebagai negara perokok terbanyak. Rokok adalah hasil olahan tembakau dan dalam sebatang rokok mengandung 4000 bahan kimia yang sangat berbahaya dan tiga kandungan rokok yang paling berbahaya adalah tar, nikotin, dan karbon monoksida. Paparan asap rokok terus menerus menimbulkan berbagai penyakit seperti kerusakan fungsi hati. Hati merupakan organ penting yang berfungsi untuk melakukan proses metabolisme dan detoksifikasi. Kerusakan hati dapat diketahui dengan meningkatnya kadar SGPT dalam aliran darah. SGPT merupakan enzim yang banyak ditemukan pada sel hati serta efektif untuk mendiagnosis destruksi hepatoseluler. Penelitian ini bertujuan untuk mengetahui kadar SGPT perokok aktif pada usia 17 - 25 tahun dengan lama merokok $<10$ tahun. Penelitian ini merupakan penelitian deskriptif dengan desain penelitian Croos Sectional. Tekhnik pengambilan sampel adalah purposive sampling. Hasil penelitian ini menunjukan 11 sampel memiliki kadar SGPT yang normal termasuk perokok ringan - sedang dan 4 sampel yang mengalami peningkatan kadar SGPT yang termasuk kedalam kategori perokok berat. Berdasarkan penelitian yang telah dilakukan, dapat disimpulkan gambaran kadar SGPT perokok aktif pada usia 17 - 25 tahun dengan lama merokok $<10$ tahun bahwa perokok aktif dalam kategori ringan hingga sedang berada dalam batas normal, sedangkan perokok aktif kategori berat mengalami peningkatan kadar SGPT.
\end{abstract}

Kata Kunci : kadar SGPT, perokok aktif, usia $17-25$ tahun, lama merokok $<10$ tahun

Abstract : A data from WHO (World Health Organization) Indonesia ranked third as the biggest country with smoker population. Cigarette was processed tobacco products and in a cigarette contains 4000 chemicals that are very dangerous and the three most dangerous cigarette content are tar, nicotine, and carbon monoxide. The exposure to smoke continuously causes various diseases such as damage to liver function.liver is an important organ that functions to carry out metabolic and detoxification processes. SGPT was an enzyme that found in liver cells and is effective for diagnosing hepatocellular destruction. This study aimed to determine the levels of SGPT active smokers at the age of 17-25 years with a duration of smoking $<10$ years. This research was used a descriptive study with cross sectional research design. The sampling technique used purposive sampling. The results of this study showed 11 samples had normal SGPT levels including mild to moderate smokers and 4 samples that experienced elevated levels of SGPT which were included in the category of heavy smokers. Based on the research that has been done, it can be concluded that the 
picture of SGPT levels of active smokers at the age of 17-25 years with a duration of smoking < 10 years that active smokers in the mild to moderate category is within normal limits, whereas active smokers in heavy categories have increased levels of SGPT.

Keywords: SGPT levels, active smokers, ages 17-25 years, duration of smoking < 10 years

\section{PENDAHULUAN}

Berdasarkan data WHO (World Health Organization) Indonesia menduduki peringkat ketiga sebagai negara perokok terbanyak (Apriora et al., 2015). Rokok merupakan hal yang dapat menimbulkan masalah kesehatan, sebanyak 65 juta penduduk indonesia merupakan perokok aktif setiap harinya (Bawuna et al., 2017). Menurut WHO usia remaja seseorang dihitung dari umur 12 24 tahun. Data RISKEDAS (Riset Kesehatan Dasar, 2018) prevelensi usia perokok remaja ada pada usia $10-18$ tahun dengan presentase menjadi $9,1 \%$. Perokok aktif dengan data dari artikel Borneo News tahun 2018 di Kalimantan tengah dengan angka 24,3\% dan ini telah melewati angka nasional yaitu $22,5 \%$. Berdasarkan data tersebut merokok dapat membahayakan bagian organ dalam tubuh manusia, paparan asap rokok terus menerus dapat menimbulkan berbagai penyakit seperti penyakit jantung, gangguan pernapasan, kanker dan fungsi hati (Tanoeisan et al., 2016).

Bahan baku pembuatan rokok yang dapat menyebabkan kerusakan fungsi organ pada tubuh manusia diantaranya nikotin memiliki sifat racun bagi saraf dan juga membuat seseorang menjadi rileks dan tenang, gas karbon monoksida (CO) dan tar yang bersifat karsinogen, sehingga dapat menyebabkan iritasi dan kanker pada saluran pernapasan bagi seorang perokok (Aji et al., 2015).

Kerusakan fungsi hati disebabkan oleh asap rokok yang mengandung radikal bebas. Asap rokok yang memicu pembentukan radikal bebas tinggi yang masuk kedalam tubuh disebabkan bahan baku rokok seperti tar, nikotin dan karbon monoksida merupakan toksik utama pembentuk radikal bebas, beberapa jenis radikal bebas yang terkandung di dalam asap rokok yaitu Hidroperoxida, $\mathrm{CO}_{2}^{-}, \mathrm{C}$, Peroxy, $\mathrm{O}_{2}^{-}, \mathrm{CuOX}, \mathrm{CuGeO}_{3}$ (Nurjanah., 2015). Kerusakan fungsi hati diindikasi dengan meningkatnya kadar SGPT (Serum Glutamic Pyruvic Transaminase). SGPT merupakan enzim yang berfungsi untuk mengkatalis berbagai fungsi tubuh Enzim SGPT akan keluar dari sel hepar apabila mengalami kerusakan sehingga menyebabkan peningkatan kadar SGPT dalam serum darah (Tanoeisan et al., 2016).

Hati merupakan organ penting yang berfungsi untuk melakukan proses 
metabolisme dan detoksifikasi. Gangguan atau kerusakan pada hati dapat mengganggu proses metabolisme dan detoksifikasi. Beberapa fungsi hati sebagai pusat metabolisme protein, lemak dan karbohidrat memproduksi cairan empedu, memproduksi antikoagulan darah serta memproduksi protein plasma pembersih bilirubin dari darah membentuk sel darah merah. Untuk mengetahui normal atau tidak fungsi hati dapat diketahui dengan meningkatnya kadar SGPT dalam aliran darah (Sujono et al., 2015).

SGPT dapat juga disebut Alanin Aminotransferase (ALT) merupakan enzim yang banyak ditemukan pada sel hati serta efektif untuk mendiagnosis destruksi hepatoseluler. Enzim SGPT dalam jumlah kecil dapat juga dijumpai pada otot jantung, ginjal dan otot rangka. Pada umumnya tes SGPT memiliki nilai lebih tinggi dari SGOT pada kerusakan parenkim hati akut, sedangkan pada proses kronis terjadi hal sebaliknya. SGPT pada umumnya dapat diperiksa secara fotometri atau spektrofotometri, secara semi otomatis atau otomatis. Kadar normal SGPT pada dewasa adalah $0-42 \mathrm{U} / \mathrm{L}$ untuk laki - laki dan 0 - 32 U/L untuk perempuan. Faktor yang dapat mempengaruhi hasil pemeriksaan kadar SGPT : (1) trauma pada proses pengambilan sampel akibat tidak sekali tusuk karena dapat meningkatkan kadar.
(2) hemolisis sampel darah. (3) obat obatan yang dapat meningkatkan kadar SGPT : antibiotik (tetrasiklin, eritromisin dan gentamisin), anti hipertensi (metildopa dan guanetidin). (4) zat salisilat dapat menurunkan atau meningkatkan kadar SGPT (Adeatma, 2014).

Berdasarkan uraian mengenai gambaran kadar SGPT pada perokok aktif usia remaja, maka penulis bermaksud melakukan analisis kadar SGPT pada perokok aktif usia remaja di Pangkalan bun.

\section{METODE PENELITIAN}

Jenis Penelitian yang digunakan adalah deskriptif dengan pendekatan cross sectional dengan sampel darah vena yang diambil berasal dari remaja berusia 17 sampai 25 tahun yang berjumlah 15 orang. Penelitian ini dilakukan mulai sejak bulan Februari 2019 dari proses penyusunan awal, pengumpulan data, pembuatan proposal penelitian sampai dengan ujian akhir KTI dibulan 09 September 2019.

\section{HASIL PENELITIAN}

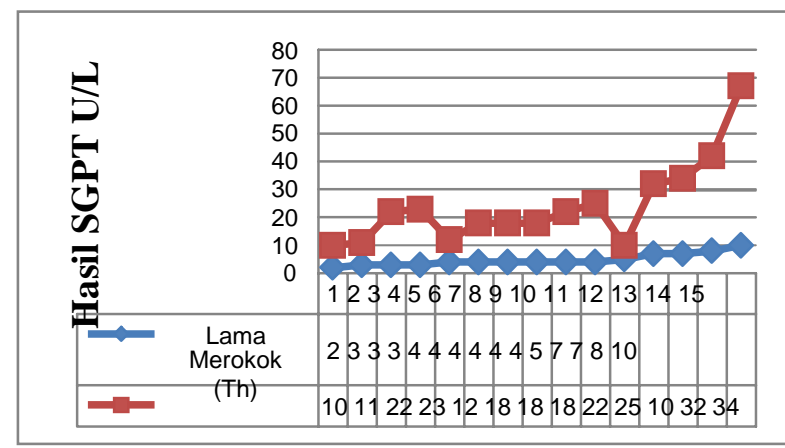

Gambar 5.1 Grafik Hasil Pemeriksaan SGPT 
Sampel penelitian ini adalah remaja usia

17 -25 tahun yang merupakan seorang perokok aktif. Jumlah sampel pada penelitian ini adalah 15 orang. Berdasarkan usia, sampel terbanyak berusia 21 dan 22 tahun dengan jumlah masing masing 5 orang. Berdasarkan lama merokok, responden minimum merokok selama 2 tahun dan responden maksimum merokok selama 10 tahun.

Tabel 5.1 Tabel Hasil Jumlah Rokok Yang Dikonsumsi

\begin{tabular}{|c|c|c|c|}
\hline Kategori & $\begin{array}{l}\text { Responde } \\
\text { n }\end{array}$ & $\begin{array}{c}\text { Lama } \\
\text { merokok }\end{array}$ & Hasil \\
\hline \multirow{5}{*}{$\begin{array}{c}\text { Ringan } \\
1 \text { - } 10 \text { Batang / } \\
\text { Hari }\end{array}$} & \multirow{2}{*}{ In. E } & 2 Tahun & $10 \mathrm{U} / \mathrm{L}$ \\
\hline & & 5 Tahun & $10 \mathrm{U} / \mathrm{L}$ \\
\hline & Tn. Ar & 4 Tahun & $12 \mathrm{U} / \mathrm{L}$ \\
\hline & Tn. Ag & 4 Tahun & $18 \mathrm{U} / \mathrm{L}$ \\
\hline & Tn. S & 3 Tahun & $11 \mathrm{U} / \mathrm{L}$ \\
\hline \multirow{6}{*}{$\begin{array}{c}\text { Sedang } \\
11-20 \text { Batang } \\
\text { / Hari }\end{array}$} & Tn. G & 4 Tahun & $18 \mathrm{U} / \mathrm{L}$ \\
\hline & III. K & 4 Tahun & $18 \mathrm{U} / \mathrm{L}$ \\
\hline & In. V & 3 Tahun & $22 \mathrm{U} / \mathrm{L}$ \\
\hline & In. $\mathrm{H}$ & 3 Tahun & $23 \mathrm{U} / \mathrm{L}$ \\
\hline & $\begin{array}{l}\text { Tn. } \\
\text { A }\end{array}$ & 4 Tahun & $25 \mathrm{U} / \mathrm{L}$ \\
\hline & Tn. L & 4 Tahun & $22 \mathrm{U} / \mathrm{L}$ \\
\hline \multirow{4}{*}{$\begin{array}{c}\underset{>}{\text { Berat }} \\
\text { 20Batang / } \\
\text { Hari }\end{array}$} & $\begin{array}{l}\text { Tn. } \\
\text { Ro }\end{array}$ & 7 Tahun & $32 \mathrm{U} / \mathrm{L}$ \\
\hline & Tn. T & 7 Tahun & $34 \mathrm{U} / \mathrm{L}$ \\
\hline & $\begin{array}{l}\text { Tn. } \\
\mathrm{Da}\end{array}$ & 8 Tahun & $42 \mathrm{U} / \mathrm{L}$ \\
\hline & Tn. Re & 10 Tahun & $67 \mathrm{U} / \mathrm{L}$ \\
\hline
\end{tabular}

\section{PEMBAHASAN}

Hasil pemeriksaan laboratorium pada penelitian ini menunjukan $73 \%$ sampel memiliki kadar SGPT yang normal yang termasuk perokok ringan - sedang dan 1 perokok berat. Sedangkan $27 \%$ sampel mengalami peningkatan kadar SGPT pada perokok berat. Sampel penelitian yang tertinggi pada Tn. Re dengan lama merokok 10 tahun yang termasuk perokok berat kadar SGPT $67 \mathrm{U} / \mathrm{L}$, normalnya kadar SGPT adalah $0-45$ U/L.hasil ini meningkat melewati angka normal. Sesuai dengan penelitian Sidi et al., (2018) toksisitas suatu zat ditentukan oleh besarnya paparan atau jumlah rokok yang dikonsumsi, dimana semakin banyak jumlah rokok yang dikonsumsi maka semakin tinggi resiko terkena berbagai macam penyakit. Pada penelitian ini semakin banyak jumlah rokok yang dikonsumsi atau perokok berat dapat meningkatkan kadar SGPT. Hasil penelitian ini sesuai dengan Tanoeisan et al., (2016) terjadinya peningkatan kadar SGPT secara signifikan pada perokok aktif. Peningkatan yang signifikan terjadi pada perokok berat akan tetapi tidak pada perokok ringan dan sedang.

SGPT merupakan enzim yang paling sering ditemukan pada sel hati sehingga sangat efektif untuk mendiagnosis kerusakan hepar, menurut Tanoeisan et al., (2016) hepar memiliki kapasitas tinggi untuk menetralkan racun yang masuk kedalam tubuh, enzim SGPT akan keluar dari sel hepar apabila sel hepar mengalami kerusakan sehingga menyebabkan peningkatan kadar SGPT dalam serum darah, maka dari itu SGPT lebih spesifik untuk menilai kerusakan hepar.

Adanya peningkatan SGPT ini terjadi karena kerusakan sel hepar yang ditunjukan dengan keanikan kadar SGPT yang disebabkan oleh rokok karena rokok 
memiliki kandungan karbon monoksida (CO), tar dan nikotin. Menurut penelitian Aji et al., (2015) karbon monoksida (CO) merupakan gas yang dihasilkan dari pembakaran tidak sempurna yang memiliki kecenderungan kuat untuk berikatan dengan hemoglobin dalam sel - sel darah merah sehingga gas $\mathrm{CO}$ ini merebut posisi oksigen di sisi hemoglobin. Kadar gas CO dalam darah perokok mencapai $4-15$ persen.

Tar, nikotin dan karbon monoksida merupakan toksik utama yang dapat membentuk radikal bebas tersebut. Meskipun asap rokok tidak berefek langsung kedalam sel hepar, akan tetapi senyawa toksik tersebut yang diabsorbsi dari alveolus ke dalam darah dapat mencapai hepar dan memicu kerusakan yang bersifat irreversibel pada sel hepar. Mekanisme meningkatnya kadar SGPT bermula dari asap rokok yang mengandung zat kimia dihirup dan masuk kedalam paru - paru kemudian masuk kedalam aliran darah karena sifat dari CO yang cenderung kuat berikatan dengan hemoglobin dan terdistribusikan ke seluruh tubuh. SGPT yang merupakan salah satu enzim dihepar mengikat zat kimia yang beredar di aliran dalam darah sehingga enzim ini akan keluar dari sel hepar dan menyebabkan peningkatan kadar SGPT dalam serum darah. Merokok menyebabkan peroksidase lipid yang menyebabkan kerusakan membran sel hepar. Pada intinya radikal bebas yang masuk kedalam tubuh membuat sel hepar dalam keadaan stress oksidatif (Roza et al., 2017).

Pada grafik dan table 5.1 diketahui beberapa data bahwa lama merokok tidak berbanding lurus dengan kadar SGPT karana adanya faktor lain yang mempengaruhi. Tn. S dan Tn. D dengan lama merokok 3 tahun mempunyai kadar SGPT yang berbeda. Tn. S dengan kadar SGPT 11 U/L dan Tn. D dengan kadar 22 U/L. Perbedaan ini terjadi karena Tn. D lebih banyak mengonsumsi rokok $11-20$ batang/ hari dan ini memasuki kategori perokok sedang, akan tetapi masih dalam batas normal kadar SGPT yaitu 0 - 45 U/L

Tn. H dengan lama merokok 3 tahun yang termasuk perokok sedang dengan hasil $23 \mathrm{U} / \mathrm{L}$ dan Tn. Ar yang termasuk perokok ringan dengan lama merokok 4 tahun serta kadar SGPT 12 U/L. Perbedaan ini dikarenalan Tn. H memiliki aktivitas sering berolahraga berat dan kebiasaan berkumpul dengan sesama perokok, sedangkan Tn. Ar yang merupakan sudah berkeluarga selalu melakukan pola hidup sehat dan saat ini dalam proses puasa merokok. Menurut Zakaria (2015), Latihan fisik yang berat dapat memicu ketidakseimbangan antara produksi radikal bebas dengan antioksidan tubuh, hal ini disebut stress oksidatif, 
dalam keadaan latihan fisik berat konsumsi oksigen di dalam tubuh dapat meningkat 20 kali. Berbeda saat kelelahan normal radikal bebas terbentuk sangat perlahan, $5 \%$ dari konsumsi oksigen akan membentuk radikal kemudian dinetralisir oleh antioksidan yang ada dalam tubuh. Akan tetapi jika laju pembentukan radikal bebas sangat meningkat melebihi 5\% dikarenakan oleh aktifitas berat, jumlah radikal bebas akan melebihi kemampuan kapasitas sistem pertahanan antioksidan.

Tn. A dengan lama merokok 4 tahun yang termasuk perokok sedang dengan Hasil SGPT $25 \mathrm{U} / \mathrm{L}$ dan Tn. E dengan lama merokok 5 tahun yang termasuk perokok ringan dengan hasil 10 U/L. Perbedaan ini terjadi karena Tn. A merupakan seorang peminum alkohol dengan merokok sedang, dalam kesehariannya Tn. A seorang Mahasiswa di Pangkalanbun, gaya hidup dari responden ini biasanya merokok disertai meminum alkohol dan 1 minggu sebelum menjadi responden Tn. A melakukan aktivitas tersebut. Seseorang yang mengonsumsi alkohol terus menerus, enzim pencernaan yang mengoksidasi alkohol akan menjadi jenuh dan meningkatkan kadar alkohol darah (KAD) dengan cepat (Suaniti et al., 2012). Proses oksidasi dengan menggunakan $\mathrm{ADH}$ terutama terjadi di dalam hepar. Metabolisme alkohol oleh ADH akan menghasilkan asetaldehid. Asetaldehid merupakan produk yang sangat reaktif dan sangat beracun sehingga menyebabkan terjadinya kerusakan pada beberapa jaringan atau sel. Sedangkan Tn. E yang lebih lama merokok dibandingkan dengan Tn. A memiliki kadar SGPT lebih rendah. Karena Tn. E seorang pelajar pernah berhenti merokok selama kurang lebih 7 bulan dan beralih menggunakan vapor, hasil yang rendah ini juga di pengaruhi oleh usia yang mana usia Tn. E 17 tahun dan masih tergolong usia pertumbuhan dengan tingkat regenerasi yang tinggi.

\section{KESIMPULAN DAN SARAN}

\section{Kesimpulan}

Berdasarkan penelitian yang sudah dilakukan kadar SGPT pada perokok aktif usia 17 - 25 tahun dengan lama merokok < 10 tahun disimpulkan bahwa perokok aktif dalam kategori ringan hingga sedang SGPT berada dalam batas normal, sedangkan perokok aktif kategori berat mengalami peningkatan SGPT.

\section{Saran}

1. Dihimbau kepada seluruh responden supaya berhenti merokok karena merokok dapat meningkatkan kadar SGPT yang merupakan penanda kerusakan hati.

2. Perlu dilakukan penelitian lebih lanjut terkait gambaran kadar SGPT pada perokok aktif usia 17 - 25 tahun 
dengan lama merokok $<10$ tahun dengan menambah jumlah sampel lebih banyak serta populasi yang tersebar dapat mewakili disetiap titik.

\section{DAFTAR PUSTAKA}

Abdullah, N., A. Suhendi dan Suwandi. 2019. Perancangan Dan Realisasi Alat Penyaring Hidrogen, Metana Dan Karbon Monoksida Yang Terkandung Dalam Asap Rokok Berbasis Arduino Uno. Proceeding Of Engineering. 6 (1) : 1212 - 1218.

Nasution, A.Y., P. Adi dan P. A. Santosa. 2015. Pengaruh Ekstrak Propolis Terhadap Kadar SGOT (Serum Glutamic Oxaloacetic Transaminase) dan SGPT (Serum Glutamic Pyruvic Transaminase) Pada Tikus Putih (Rattus norvegicus) Galur Wistar Dengan Diet Tinggi Lemak. Majalah Kesehatan FKUB. 2 (3) : $120-126$.

Adeatma, N. W. 2014. Uji Efektivitas Protein Biji Melinjo (Gnetum gnemon L.) Terhidrolisis Sebagai Hepatoprotektor Terhadap Radikal Bebas Dalam Mencegah Peningkatan Kadar SGOT dan SGPT Tikus Wistar Yang Diinduksi $\mathrm{CCL}_{4}$. Skripsi. Universitas Jember. Jember.

Aji, A., L. Maulinda dan S. Amin. 2015, Isolasi Nikotin Dari Puntung Rokok Sebagai Insektisida. Jurnal Teknologi Kimia Unimal. 4 (1) : 100 -120 .

Amalia, N. M. 2015. Analisis Pengaruh Konsumsi Rokok Terhadap Produktivitas Tenaga Kerja Di Indonesia. Jurnal Pendidikan Dan Ekonomi, 7 (2) : 162 - 174.
Anjelisa, T. dan S. Ruhi. 2018. Pengaruh Pemberian Obat Terhadap Tingginya Kadar Enzim Serum Glutamate Oksaloasetat Transaminase (SGOT) Dan Serum Glutamate Piruvat Transaminase (SGPT) Pada Pasien Gangguan Jiwa Di RS Jiwa Provinsi Sulawesi Tenggara. Jurnal MediLab Mandala Waluya Kendari. 2 (1) : 49 -53 .

Apriora, V. D., A. Amir dan O. Khairsyaf. 2015. Gambaran Morfologi Spermatozoa Pada Perokok Sedang di Lingkungan PE Group Yang Datang ke Bagian Biologi Fakultas Kedokteran Universitas Andalas. Jurnal Kesehatan Andalas. 4 (2): $425-429$.

Basuki, P. P., H. Febriani. 2016. Hubungan Antara Kriteria Perokok Dengan Kejadian Infeksi Saluran Pernapasan Akut (Ispa) Pada Balita Di Wilayah Kerja Kecamatan Prambanan Yogyakarta. Karya Tulis Ilmiah. Sekolah Tinggi Ilmu Kesehatan Wira Husada Yogyakarta . Yogyakarta.

Bawuna, N. H., J. Rottie dan F. Onibala. 2017. Hubungan Antara Tingkat Stres Dengan Perilaku Merokok Pada Mahasiswa Fakultas Teknik Universitas Sam Ratulangi. Jurnal Keperawatan. 5 (2) : $1-8$.

Departemen Kesehatan R.I.. 2007. Pharmaceutical Care untuk Penyakit Hati. Jakarta.

Horax, M., L. W. Santoso dan K. Gunadi. 2017. Media Interaktif Tentang Bahaya Merokok Bagi Pelajar. Fakultas Teknologi Industri Universitas Kristen Petra. Surabaya.

Riskesdas. 2013. Perilaku Merokok Masyarakat Indonesia. Pusat Data Dan Informasi Kementrian Kesehatan RI. Kemenkes. 
Mirdayanti., D. E. Artha dan H. Yahya. 2018. Hubungan Kadar Serum Glutamat Piruvat Transaminase (SGPT) dan Kadar Trigliserida Pada Pasien Penyakit Jantung Koroner. Jurnal Media Laboran. 8 (2) : 28 33.

Notoatmodjo, S., 2010. Mengembangkan Instrumen Penelitian. Dalam : Notoatmodjo, S., ed. Metodologi Penelitian Kesehatan. Rineka Cipta. Jakarta.

Notoatmodjo, S. 2005. Metodologi Penelitian Kesehatan. Rineka Cipta. Jakarta.

Nurjanah, H. U., 2015. Hubungan Kadar Serum Glutamat Piruvat Transaminase (SGPT) dan Kadar Trigliserida Pada Pasien Penyakit Jantung Koroner. Skripsi. Universitas Islam Negeri Maulana Malik Ibrahim. Malang.

Nursalam. 2003. Konsep dan Penerapan Metodologi Penelitian Ilmu Keperawatan. Salemba Medika. Jakarta.

Nurzali, E. 2013. Pengaruh Pemberian Boraks Dosis Bertingkat Terhadap Perubahan Makroskopis dan Mikroskopis Hepar Tikus Wistar Selama 4 Minggu dan 2 Minggu Tanpa Boraks. Karya Tulis Ilmiah. Universitas Diponegoro. Semarang.

Roza, Y. N., F. Oenzil dan D. Pertiwi. 2017. Hubungan Antara Merokok dan Tingkat Aktivitas Aminotransferase Serum Pada Pegawai Kantor. Jurnal Kesehatan Andalas. 6 (2) : 409 - 416.

Sidi, M., E. P. Sari dan D. Y. Kristianingrum. 2018. Gambaran Kadar SGPT (Serum Glutamic Pyruvic Transaminase) Pada
Perokok Aktif. Karya Tulis ilmiah. Sekolah Tinggi Ilmu Kesehatan Insan Cendekia Medika. Jombang.

Suaniti, N. M, A. A. G. S. Djelantik, K. Suastika dan N. M. Astawa. 2012. Kerusakan Hati Akibat Keracunan Alkohol Berulang Pada Tikus Wistar. Jurnal Veteriner. 13 (2) : $199-204$.

Sugiyono. 2005. Metode Penelitian Empiris. Penerbit Yayasan Obor. Jakarta.

Sugiyono. 2011.Metode Penelitian Bisnis. Cetakan Ketujuh. CV Alfabeta. Bandung.

Sujono, T. A., A. S. Wahyuni, M. Da'i, I. T. D. Kusumowati, A. Suhendi, R. Munawaroh, N. Pratiwi, S. Fauziyyah, R. Rahadini dan S. Lestari. 2015. Pengaruh Pemberian Ekstrak Etanol Meniran (Phyllanthus ninuri L) Selama 90 Hari Terhadap Fungsi Hati Tikus. Universitas Muhammadiyah Surakarta. Surakarta.

Tanoeisan, A. P., Y. M. Mewo dan S. H. M. Kaligis. 2016. Gambaran Kadar Serum Glutamic Pyruvic Transaminase (SGPT) Pada Perokok Aktif Usia > 40 Tahun. Skripsi. Universitas Sam Ratulangi Manado. Manado.

WHO. 2019. Who Report On The Global Tobacco Epidemic.WHO Document Production Services. Geneva. Switzerland.

Zakaria, F. 2015. Efek Latihan Fisik Maksimal Terhadap Tingkat Kerusakan Faal Hati Dengan Menggunakan Test Serum Glutamate Piruvate Transaminase (SGPT). Skripsi. Universitas Negeri Semarang. Semarang. 